\title{
Increased Peak Expiratory Flowrate
}

National Cancer Institute

\section{Source}

National Cancer Institute. Increased Peak Expiratory Flowrate. NCI Thesaurus. Code C50610.

An increase of the greatest rate of flow that can be achieved during forced expiration beginning with the lungs fully inflated. 